Influence of Financial Behavior, Financial Stress and Locus of Control on Financial Well-Being among B40 Households in Selangor During the Pandemic

Amirah Shazana Magli, Mohamad Fazli Sabri, Husniyah Abdul Rahim \& Mohd Amim Othman

To Link this Article: http://dx.doi.org/10.6007/IJARBSS/v11-i12/11792

DOI:10.6007/IJARBSS/v11-i12/11792

Received: 11 October 2021, Revised: 14 November 2021, Accepted: 30 November 2021

Published Online: 17 December 2021

In-Text Citation: (Magli et al., 2021)

To Cite this Article: Magli, A. S., Sabri, M. F., Rahim, H. A., \& Othman, M. A. (2021). Influence of Financial Behavior, Financial Stress and Locus of Control on Financial Well-Being among B40 Households in Selangor During the Pandemic. International Journal of Academic Research in Business and Social Sciences, 11(12), $467-486$.

Copyright: (c) 2021 The Author(s)

Published by Human Resource Management Academic Research Society (www.hrmars.com)

This article is published under the Creative Commons Attribution (CC BY 4.0) license. Anyone may reproduce, distribute, translate and create derivative works of this article (for both commercial and non0-commercial purposes), subject to full attribution to the original publication and authors. The full terms of this license may be seen

at: http://creativecommons.org/licences/by/4.0/legalcode

Vol. 11, No. 12, 2021, Pg. $467-486$

http://hrmars.com/index.php/pages/detail/IJARBSS

JOURNAL HOMEPAGE

Full Terms \& Conditions of access and use can be found at http://hrmars.com/index.php/pages/detail/publication-ethics 


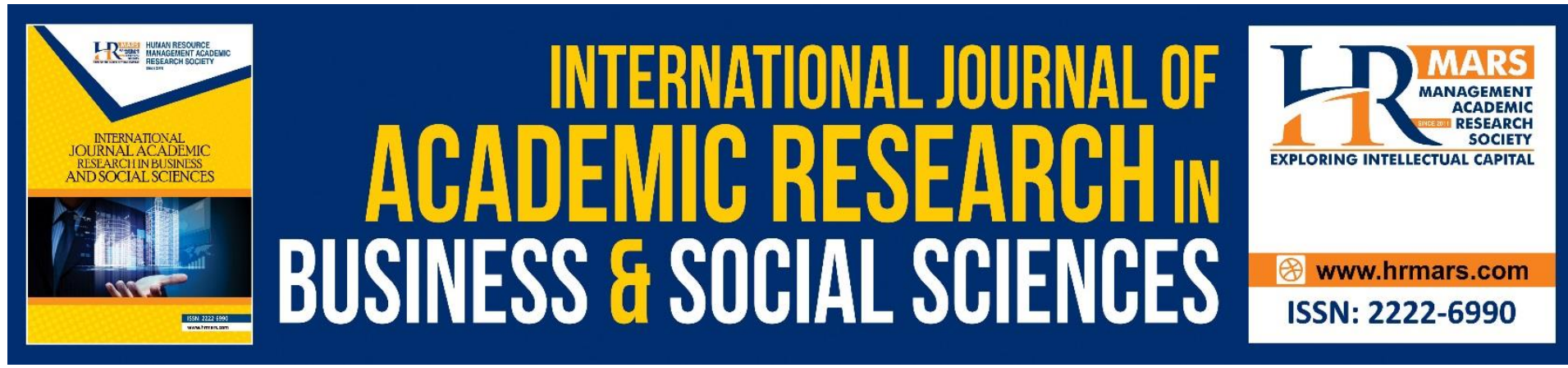

\title{
Influence of Financial Behavior, Financial Stress and Locus of Control on Financial Well-Being among B40 Households in Selangor During the Pandemic
}

\author{
Amirah Shazana Magli, Mohamad Fazli Sabri, Husniyah Abdul \\ Rahim \& Mohd Amim Othman
}

Department of Resource Management \& Consumer Studies, Faculty of Human Ecology, University Putra Malaysia, 43400 Serdang, Selangor, Malaysia.

Email: fazli@upm.edu.my

\begin{abstract}
Economic disadvantage disproportionately affects B40 households with income shocks. This paper aims to analyse the effects of financial well-being on 428 respondents from B40 households in Selangor districts using non-probability sampling (purposive stratified sample). SPSS Version 26 was used to perform regression analyses to determine factors influencing financial behaviour, financial stress, and locus of control. The fitness of the financial wellbeing model indicated an R-square value of 0.386 . The model explained 38.6 per cent of the variances in financial well-being. Financial well-being was explained by the model's factors comprising financial behaviour, financial stress, internal and external locus of control. Model indicated ( $F=65.70 ; p=.000)$ were valid models based on the ANOVA output. Financial behaviour and internal locus of control were shown to positively impact financial well-being; whereby financial stress was negatively influencing financial well-being. Financial stress occurs when a person's financial resources are insufficient to meet basic financial needs. Henceforth, those under a lot of financial stress must engage in proper financial activities to be more financially independent. In conclusion, ensuring responsible practices, including excellent financial behaviour practices, strong financial stress management, and high internal locus of control strengthened would assist households in completing their financial management.
\end{abstract}

Keywords: B40 Households, Financial Behavior, Financial Stress, Financial Well-Being, Locus of Control

\section{Introduction}

The emergence of COVID-19 has prompted the Malaysian government to impose the Movement Control Order (MCO) on March 18, 2020. According to Bank Negara Malaysia, the implementation of MCO has a negative impact on national income, with Malaysia's economic growth anticipated to be between $-2 \%$ and $0.5 \%$ in 2020 (Ismail et al., 2021). The impact of 
MCO caused by COVID-19 affects the micro level and the micro level, particularly those groups of households. Malaysia is a developing country to become a high-income nation by the year 2020. Hence, financial well-being is crucial, as success in increasing economic well-being can lead to success in lowering poverty rates.

COVID-19 pandemic has indirectly caused an economic crisis, cause an impact on how individuals spend, save, invest, and manage risks to protect their financial well-being, particularly in long-term planning. This dramatic phenomenon has been accompanied by a severe economic downturn, which has had a detrimental effect on both individual income and the nation's financial position. This circumstance has increased the number of households experiencing issues repaying secured or unsecured debt, rent arrears, and the ability to cover unforeseen bills.

Hence, the study of financial well-being and the influence of financial behaviour, financial stress and locus of control on financial well-being households is an integral part of household research. Financial well-being is crucial to the family study as a consumer unit, as it contributes to consumer and family financial management and the community's financial well-being. Financial well-being affects not only low-income individuals and families but also all aspects of individuals and families. Thus, the objective of this paper is to analyse and contributes to empirical research of the financial well-being of B40 households and the effect of financial behaviour, financial stress, and locus of control on financial well-being during Malaysia's pandemic recession.

\section{Literature Review}

\section{The Movement Control Order (MCO)}

The COVID-19 pandemic has grown into health, socioeconomic, and general humanitarian crisis of unprecedented scale and impact. Even though people are distressed, particularly those who work in small and medium enterprises, the government must extend the MCO timeframe to reduce the possibility of the public becoming infected with COVID-19 due to occasional cases or not realising they are sick. Malaysia's predicament is made worse by the country's enormous debt burden, financial limits, falling oil prices, and the global shutdown's knock-on consequences for trade and tourism. On the economic front, the lockdown is threatening to destabilise the economy. The economy is collapsing, having a negative effect on employment, earnings, and livelihoods, upending supply chains and upending enterprises, and worsening inequality, poverty, and difficulties, particularly among the most vulnerable B40 income household group. This demonstrates unequivocally that the implementation of MCO affected household consumption.

According to the Department of Statistics Malaysia's (2020) MCO effect assessment on households, average consumer spending, excluding financial expenditure, they were reduced by RM1,923 (48 per cent) to RM2,110 under MCO. Higher living costs have already pressured the B40 group. The pandemic in COVID-19 has added concern about economic issues like job stability and security and the school development of their children.

\section{Financial Well-Being}

The financial well-being concept is extensively used in many types of research. However, due to its broad perception, there is no comprehensively constructed definition or measurement of financial well-being, particularly on conceptualization and component. In general, financial 
well-being is defined as having good financial security with freedom of choice and overall satisfaction in present-day and forthcoming (Benjamin et al., 2014). Past researchers had assessed financial well-being in many types of different scales, and literature indicates that financial well-being has been grouped into two distinctive groups- objective and subjective financial well-being.

Nonetheless, throughout literature, mainly researchers are likely to use objective and subjective characteristics, or objective or subjective characteristics, to define financial wellbeing. Conferring to Van Praag et al. (2003), financial well-being has been designated in objective and subjective measures, where they can also be acknowledged as financial wellness (Mokhtar \& Rahim, 2017).

The objective scale of economic statuses is measured using economic status like income, consumption, wealth, and assets. Various researchers used objective scale precisely the amount of money (Williams, 1983), savings and income (Porter, 1990), the comparison between baby boomers and their parents on their income and consumption (Sabelhaus \& Manchester, 1995) and total family income (Fletcher \& Lorenz, 1985) to measure economic well-being.

Financial well-being has been defined in various ways; in economic, services marketing, social, household level, financial counselling and planning, developmental psychology, and consumer decision making (Aggarwal, 2014; Brüggen et al., 2017). However, this paper focuses specifically on the determinants and measurements of financial well-being at the household level in selected three states -develop, developing and underdeveloped countries. On the contrary, this paper attempts to fill the gap to designate the commonly used variables in past literature.

Previously, the definition of financial well-being was commonly on happiness or satisfaction with one's financial ownership. However, presently, the definitions have shifted towards an individual's attentiveness to improving people's quality of life and standard of living (Joo, 1998).

Over the past decades, various variables have been applied to examine the financial wellbeing of households, for example, household income, financial debt, economic, social, financial health, and psychology (Arendt \& Brettel, 2010; Nickerson et al., 2007; Por et al., 2011; Sabri \& Zakaria, 2015). However, financial well-being cannot be measured only by considering these few variables. It encompasses multiple determinants of financial wellbeing, and researchers should focus on different angles. Hence, every country might apply distinctive variables suited to describe and examine the country's financial well-being. Consequently, Table 1 summarises variables, samples, sampling techniques, and findings presented by various countries.

The report in developed countries has shown that 74 per cent of United States adults were found relatively satisfied with their financial condition (Anderson et al., 2015). Surprisingly, issues on financial strains were reported as the highest problem confronted by the U.S household, especially on financial stress management (Board of Governors of the Federal Reserve System, 2018). CFBD also (2015b) reported that rates of material hardship and financial struggles were extremely high in households and thus conveyed lower levels of financial well-being. On the contrary, households with low financial stresses were found to 
have higher levels of financial well-being. However, a researcher needs to note that higher incomes did not always portray a higher well-being level for every individual.

However, according to Waqar et al (2019), the direct impact of self-control on financial wellbeing presents a non-significant impact. Meanwhile, the relationship between financial behaviour towards financial well-being shows more significant results than financial literacy and self-control towards financial well-being. This paper, however, did highlight the importance of understanding the role of self-control and financial behaviour, as this behaviour commits to building a good character of the individual to be more confident in managing their financial facet and preparing future retirement.

In summary, although an abundance of research uses different variables and comes out with different results, one may consider the dissimilarities in the period and place of investigation. These differences can indicate different meanings and measures of an individual's financial well-being and their relationship between variables (Taft et al., 2013).

\section{Financial Behaviour}

Financial behaviours are acts, emotions, or performances related to money management carried out specifically (Gorham et al., 1998). Individuals participate in financial behaviours such as managing cash, credit, and savings daily, and these behaviours have an impact on their financial well-being (Dew and Xiao 2011). Effective financial behaviour can be defined as any behaviour that results in that leads to the achievement of one's financial goals, such as maintaining cash flow documentation, planning expenses, paying utility bills, and controlling the use of credit cards and savings accounts (Gorham et al. 1998; Xiao 2008). Conversely, poor financial behaviour includes overspending, ineffective debt management, and late payments of bills (Xiao et al., 2009).

Previous research has shown that financial behaviour has a significant impact on an individual's financial well-being. According to these studies, financial well-being is correlated with positive financial behaviours, whereas negative financial behaviours are influenced by financial concerns and accompanying stress. Godwin (1994), for example, examined the relationship between the financial flow management process and outcome in newlywed couples. According to the research, couples who manage their cash flow well are happier financially than their peers. Joo and Grable (2004) replicated the study conducted by O'Neill et al. (2000) on the association between financial behaviour and financial satisfaction. The two research outcomes are consistent in that respondents who demonstrated good financial behaviour have higher financial well-being.

Recent research by Xiao et al (2014) found similar findings. Their study investigates the relationships between consumer financial behaviour and financial satisfaction in the United States and contends that consumers who engage in desired financial behaviours would experience greater financial well-being.

Additionally, considerable research has been conducted on the impacts of financial behaviour and financial well-being in Malaysia. Falahati et al (2012) examined the saving and spending behaviours of 700 university students in Malaysia and discovered that positive financial behaviours increased respondents' financial well-being. According to the findings of a study 
on financial well-being and indebtedness among Malaysian employees, healthy personal finances are a critical component that must be established early on to address financial distress (Subramaniam et al., 2014). Based on the discussion above, this study hypothesises the following:

H1: Effective financial behaviour results in increased financial well-being among $B 40$ Households in Selangor.

\section{Financial Stress}

Financial stress is described as financial strains that arise when a person is exposed to undesirable events such as changes in one's present financial situation or facing an emergency that necessitates a sum of money above the individual's typical financial capacity (Voydanoff, 1990; Kim et al., 2006). It should be noted that the idea differs from financial distress in that financial stress refers to significant financial shocks or changes in one's life. In contrast, financial distress is the inverse of financial well-being. According to Yates (2007), financial stress is caused by an inability to meet basic financial needs to maintain a certain standard of living. Other experts postulate that financial stress derives from three primary sources: personal (e.g., injuries and illness), family (e.g., marriages and births), and financial shocks (e.g., foreclosure, significant drops in savings, and legal issues) (Joo and Grable, 2004; Prawitz et al., 2006). According to Boss (2001), accumulating financial stress, such as increasing debt or financial shortfalls, could lead to financial distress (Boss, 2001) or, conversely, leads to low financial well-being.

Financial stress can have a significant impact on one's general well-being, including health concerns (Kim et al., 2006; Drentea and Lavrakas, 2000; Jacobson et al., 1996; O'Neill et al., 2005) and lowering work performance (Kim et al., 2006). According to Xiao et al (2006), financial stress is related to increased debt levels and contributes to the degradation of health and family relationships. In comparison, Lyons and Yilmazer (2005) could not establish the influence of financial stress on one's health but discover a significant effect of health on financial stress. Their argument was that an unhealthy individual would have difficulties managing their finances, therefore exacerbating their financial pressure or stress.

Starrin et al (2009) state that, individuals especially in lower-income groups, are more vulnerable to psychological health risks when dealing with financial stress because they are more guilty or resentful of their condition than those in lower-income groups. Studies show that financial stress has negatively impacted an individual's financial circumstances, based on the available research. Hence, disruptions or degradation of these conditions would certainly negatively influence an individual's financial well-being. As a result, this study suggests a hypothesis that:

H2: Financial stress is negatively interrelated to the financial well-being among $B 40$ Households in Selangor.

\section{Locus of Control (LOC)}

The term "locus of control" originates from the area of psychology and refers to an individual's attitude, belief, or expectation about his or her behaviour and the consequences (rewards or penalties) (Rotter 1966). In the instance of personal financing, Lefcourt (1976) claimed that locus of control is vital in balancing an individual's financial stresses and creating improved financial behaviour to enhance financial enforcement, particularly among B40 households. 
Internal and external perspectives can be viewed to examine the concept of locus of control (LOC). Individuals with an internal locus of control are more likely to be optimistic and drive their determinations toward their desired goals (Lefcourt, 1976; Hellriegel et al., 2010). The external component of LOC, on the other hand, implies that individuals tend to believe that other variables such as luck, chance, and fate affect a given outcome, even though they have no control over them (Hoffman et al., 2000). Brewin and Shapiro (1984) recommend that researchers consider these two aspects individually rather than collectively to prevent contradictory interpretations.

Insights from empirical research emphasize that higher internal LOC has been shown to increase financial satisfaction (Sumarwan and Hira, 1993) and financial well-being (Shim et al., 2009; Prawitz et al., 2013). Internal LOC has been linked to various personal financial behaviours and attitudes, according to previous research. Cobb-Clark et al. (2013) developed a LOC index and discovered that internal LOC positively impacts the degree of savings compared to total income. Salamanca et al. (2016) discovered that those with greater internal LOC perceive they have control over their outcomes, are more risk-tolerant, and hence have a higher propensity to hold more equity in their financial portfolios. According to studies, individuals with a greater internal LOC are also less likely to be in financial distress and have better levels of financial health (Prawitz and Cohart, 2016). Given that individuals with a high internal LOC believe they have control over their financial prospects, the following hypothesis is tested:

H3: Internal locus of control is positively related to the level of financial well-being among Malaysian households.

On the contrary, as past research has shown, those with external solid control positions will be more financially vulnerable, which will lead to a reduction in well-being in reaction to stresses (Debus et al., 2014). Individuals who believed external locus of control had a significant impact, on the other hand, felt they had less control over their circumstances (Deacon \& Firebaugh, 1988). As a result of the research conducted, the following hypothesis may be generated:

H4: Internal locus of control is negatively related to financial well-being among $B 40$ Households in Selangor.

\section{Conceptual Framework}

In this study, the researcher used a conceptual model to examine the impact of financial behaviour, financial stress, and locus of control as independent variables on financial wellbeing in B40 households. These characteristics ultimately connect to their financial wellbeing, which is linked to their overall life success. The conceptual framework for this investigation is represented in Figure 3.0. 


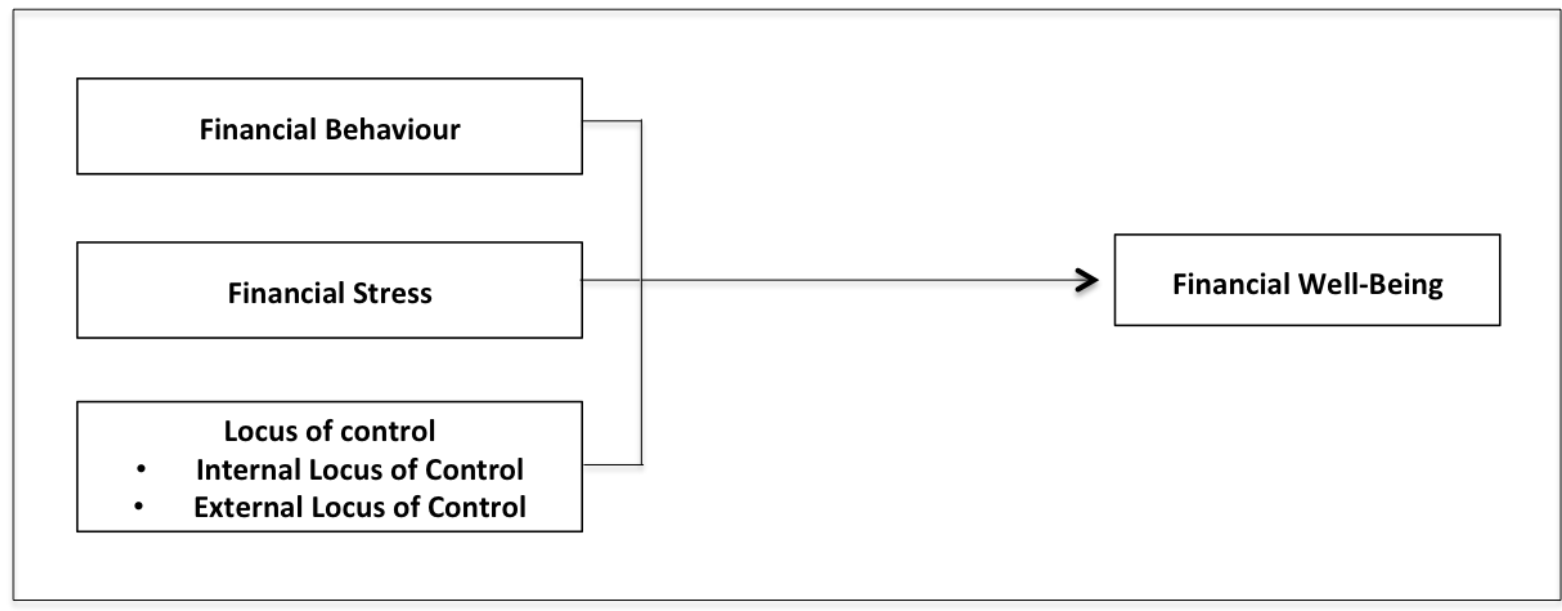

Figure 3: Conceptual Framework

The theoretical basis for this work is system theory (Maloch \& Deacon, 1966). The personal resource management process begins with input components that include demands and resources. Following that, a transaction process is used to balance both perceived demands and available resources. Subsequent output or result acts will be evaluated to determine how family demands and resources were handled and utilised. Typically, system theory encompasses a broad range of issues, including personal development, cash flow management, output planning, programme planning, and budgeting.

On the other hand, Deacon and Firebaugh's (1988) family resource management model elucidates more linkages than structure. The model is divided into two subsystems: personal and managerial. Family members utilise the individual subsystem to propagate and socialise. On the other hand, the managerial subsystem is utilised to aid in the development of family members. Throughput is a transaction process that transforms the input into output in this paradigm. Thus, this theory is entirely compatible with the analysis of the B40 household's varied features from various perspectives. The Family Resource Management model is depicted in Figure 1.0.

The Stress Theory is concerned with how individuals respond to crises or challenging events. Coping is used to alleviate stress. However, it is uncertain whether a coping strategy is successful before achieving those aims. Thus, by integrating resource management and stress theory, the efficiency of a coping mechanism for alleviating stress in a manageable strategy may be investigated using the (Dollahite model, 1991).

The theory and conceptual frameworks major strength is its broad application, making it a powerful instrument for policy analysis and formulation at all levels of development in a nation. While the technique is intended to generate the most efficient estimates utilising granular and precise microdata, a meaningful home risk assessment can be obtained from a minimal and fragmented set of information.

\section{Methodology}

\section{Sampling}

Selangor has the most populous state in peninsular Malaysia or West Malaysia (5.46 million people), with a mean income of RM10,827 and RM8,013, respectively, which was greater than 
the national average (DOS, 2020). Henceforward, Selangor has been chosen as Malaysia's best selection district region to conduct a more in-depth investigation of this study. This study employed a non-probability sample method (purposive stratified sample), with respondents were chosen based on a set of criteria. The study's respondents were household heads who lived in an urban planned city and had an annual income of less than RM6959, which categorised them in the B40 income group. Using IBM Statistical Package for Social Science (SPSS) Version 26.0, all acquired data is computed to do a regression analysis to find the financial behaviour, stress, and locus of control on financial well-being among B40 Households in Selangor.

This is a quantitative study of selected variables with a correlational analysis. Quantitative research is a helpful tool for completing studies and proving or disproving hypotheses. The variables' measurements are adapted from previous research to meet the content validity, resulting in reliabilities ranging from 0.79 to 0.91 during the actual survey. The current study required 384 respondents, as indicated by the sample size calculation at a margin of error of $5 \%$ and a confidence level of $95 \%$ (Krejcie \& Morgan, 1970). The distributed questionnaire yielded a total of 428 respondents.

\section{Non-Probability Sampling Methodology \& Purposive Data Sampling}

Data collection is essential for research since the data is designed better to comprehend the theoretical framework (Bernard, 2002). It is thus critical that the method of data collection and the source of data collection are made with caution, especially given that no amount of analysis can compensate for poorly gathered data. Non-probability sampling is commonly employed in experimental or trial research and does not reflect the intended population (Tongco, 2007).

Purposive sampling, also referred to as judgment sampling, refers to the deliberate selection of a participant based on the individual's characteristics. This entails identifying and selecting individuals or groups of knowledgeable and skilled persons about a particular phenomenon being studied. In this technique, the subjective assessment is used, and units of the population are conveniently selected (Ayhan, 2011).

Unlike random studies, which intentionally include a broad range of ages, ethnicities, and cultures, purposive sampling focuses on individuals with specific qualities better positioned to assist with the relevant study. As for this research study, respondents were chosen based on a set of criteria, which used a non-probability sample method (purposive stratified sample). Malaysian citizens who lived in the research locations were the head of household and had an income of RM4,850 or less met the study's requirements.

\section{Variable Measurements}

The questionnaire gathers data on the household's demographic and socioeconomic characteristics and spending habits. Further questions were asked about the household's background, financial well-being, financial behaviour, financial stress, and respondents' locus of control.

Financial well-being variables were measured adapted from the Malaysian context questionnaire Garman and Jariah in 2006 (Jariah, 2007). This measurement, known as the Malaysian Financial Well-Being Scale (MFWBS) with eight statements, investigated 
respondents' concern about their general satisfaction with their financial situation, ability to meet daily expenses, financial management, financial sufficiency, and current financial situation satisfaction used in this study. The responses range from Strongly Disagree (1) to Strongly Agree (5).

The B40 financial behaviours, on the other hand, were assessed using statements adapted from various measures of ten financial behaviour items from Kapoor, Dlabay, and Hughes's financial planning (2001) to assess respondents' financial goals. The cash management items used by respondents were adapted from (Hilgert and Hogarth, 2003; O'Neill, 2002; Xiao, Sorhaindo, and Garman, 2004). Credit management items developed by Hogarth and Anguelov (2004) were also adapted. Credit management items from Hogarth and Anguelov (2004) and investments savings measurement items from Hilgert and Hogarth (2003) were also adapted to measure financial behaviour. Cronbach's Alpha was reported as 0.781 for the ten statements.

Following that, Aldana and Liljengquist (1998) financial stress was assessed. The financial stress of B40 households is measured using instruments based on the respondent's adverse health effects, financial satisfaction and difficulty, and financial perception on a fivefrequency scale ranging from Never (1) to Very Frequently (5). The Cronbach's Alpha was reported to be 0.877 for the eight statements.

Finally, the locus of control measurement was adapted from Sumarwan and Hira (1993) items, including internal and external factors that determine one's belief in one's ability to control the situation. The responses range from Strongly Disagree (1) to Strongly Agree (5). The questions were evaluated on the Likert scale for four points. The Cronbach's Alpha indicated a level of reliability of 0.91 .

\section{Results \& Discussion}

The composite variable index was used to assess the normality of the distribution using Exploratory Data Analysis (EDA). Normality and scatter plots indicate that the data satisfied the assumptions of parametric normality and homoscedasticity analysis for continuous variables. Further analysis with SPSS version 26 used hierarchical multiple regressions to determine the significant Influence of financial behaviour, financial stress, and locus of control on financial well-being among B40 Households in Selangor.

The sample frequency distribution was used to ascertain the respondents' backgrounds. As indicated in Table 1.0, demographic variables such as gender, age, ethnicity, marital status, and highest degree of education were discussed in this paper. 
Table 1.0: Sample Frequency Distribution

\begin{tabular}{|c|c|c|}
\hline Variable & $\begin{array}{l}\text { Frequency } \\
(n=428)\end{array}$ & Percentage (\%) \\
\hline \multicolumn{3}{|l|}{ Gender } \\
\hline Male & 267 & 62.5 \\
\hline Female & 160 & 37.5 \\
\hline \multicolumn{3}{|l|}{ Age } \\
\hline$<20$ & 1 & 0.2 \\
\hline $20-25$ & 27 & 6.3 \\
\hline $26-30$ & 55 & 12.9 \\
\hline $31-35$ & 59 & 13.8 \\
\hline $36-40$ & 62 & 14.5 \\
\hline $41-45$ & 71 & 16.6 \\
\hline $46-50$ & 47 & 11.0 \\
\hline 50 and above & 106 & 24.8 \\
\hline \multicolumn{3}{|l|}{ Ethnicity } \\
\hline Malay & 320 & 75.1 \\
\hline Chinese & 49 & 11.5 \\
\hline Indian & 36 & 8.5 \\
\hline Others & 21 & 5.0 \\
\hline \multicolumn{3}{|l|}{ Marriage Status } \\
\hline Single & 72 & 16.2 \\
\hline Married & 314 & 73.9 \\
\hline Divorced & 5 & 8.7 \\
\hline Widowed & 37 & 1.2 \\
\hline \multicolumn{3}{|l|}{ Highest Educational Level } \\
\hline No formal education & 20 & 3.8 \\
\hline Primary School & 20 & 4.7 \\
\hline Secondary School (PMR/PT3, SPM,STPM) & 233 & 54.9 \\
\hline $\begin{array}{l}\text { Tertiary Education (Diploma/Certificate, Degree, } \\
\text { Masters, Ph.D) }\end{array}$ & 155 & 36.6 \\
\hline
\end{tabular}

\section{The Respondents' Characteristics}

In terms of gender, males made up 62.5 per cent of the participants, while females made up the rest. The questionnaires provided in this study were geared at the head of the family. As a consequence, the examined findings represent the response of the head of the household in the Selangor district.

Slightly fewer than a quarter (24.8\%) of respondents aged 50 and above. Meanwhile, others were between the ages of 41 and 45 (16.6 per cent), 36 to 40 (14.5 per cent), 31-35 (13.8 per cent), and 26-30 (12.9 per cent).

The majority of respondents (75.1\%) were Malay, followed by Chinese $(11.5 \%)$, Indians (8.5\%), and others (5.0\%). Meanwhile, over one third (36.6 per cent) of the respondents are engaged in tertiary education. Additionally, 4.7 per cent of respondents attended primary school, while 3.8 per cent reported having no formal education. At the same time, half of the respondents reported having secondary education, 54.9 per cent. This demonstrates that 
most of these respondents have completed schooling at the PMR/PT3 level and the SPM and STPM levels.

Table 2.0: Socio-Economic Information

\begin{tabular}{lll}
\hline Variable & $\mathbf{n}$ & \% \\
\hline $\begin{array}{l}\text { Employment During Covid } \\
\quad \text { Yes, Eemployed }\end{array}$ & 282 & 65.9 \\
$\quad$ No, Unemployed & 142 & 33.2 \\
$\begin{array}{l}\text { Primary Employment Sector During Covid } \\
\quad \text { Civil/Goverment Servant }\end{array}$ & 40 & $12.1 \%$ \\
$\quad$ Private Sector Employee & 217 & $65.8 \%$ \\
$\quad$ Self Employed & 73 & $22.1 \%$ \\
Monthly Income (B40 Decile Group) & & \\
B4 RM5840-RM6959 & 29 & 6.8 \\
B3 RM4660-RM5839 & 35 & 8.2 \\
B2 RM3480-RM4659 & 114 & 26.6 \\
B1 Less than RM3840 & 250 & 58.4 \\
Personal Income/ Household Income in view of & & \\
Covid-19 Pandemic & & \\
$\quad$ Higher & 30 & $7 . \%$ \\
$\quad$ No changes & 181 & $42.4 \%$ \\
$\quad$ Dropped & 216 & $50.6 \%$ \\
\hline
\end{tabular}

In terms of socioeconomic data, Table 2.0 reveals that more than two-thirds (65.9 per cent) of respondents could retain their employment throughout the COVID-19 phases. Meanwhile, 33.2 per cent reported being jobless, and COVID-19 had a negative effect on their prior careers. While $22.1 \%$ were self-employed, $12.1 \%$ were public servants.

The findings also revealed that over half of the respondents, 58.4 per cent, belong to the B40 income group (B1), with monthly earnings of less than $\mathrm{RM} 3,840.42 .4 \%$ of respondents found that they fall into the B40 income classification group (B2), where their income ranged from $\mathrm{RM} 3,480$ to RM4,659. The remaining 8.2 per cent of the small group came from B40 income classification group B3, with income ranging from RM4,660 to RM5,839, group B4, B40 income classification group, with income ranging from RM5,840 to RM6,959. Similarly, Table 3.0 provides a clearer picture of the mean total monthly expenses for 428 respondents from B40 households in Selangor, which was reported to be RM2,362.97 per month. Monthly household expenses are included for food and beverages, housing rent, utilities, daycare, transportation, and other items. 
Table 3.0: Estimated Self/Household Monthly Budget

\begin{tabular}{ll}
\hline Items & $\begin{array}{c}\text { Mean Total Expenses } \\
\text { Monthly (RM) }\end{array}$ \\
\hline Food and Drinks & \\
Housing & \\
Utilities (Water, Electricity, Internet, Astro, Phone Bill) \\
Childcare \\
Transportation \\
Education ( Tuition fees, school expenses) \\
Health and Medications (Treatment,insurance/takaful) \\
Clothing \\
Entertainment (Travelling, movies,others) \\
Hire Purchase loan ( Car, Motorcycle) \\
Personal loan repayment \\
Housing loan repayment \\
Education loan repayment \\
Credit card repayment
\end{tabular}

Table 4.0 revealed that more than a quarter (30.6 per cent) of respondents could sustain for one to three months with their savings after taking current liabilities into account. However, $27.6 \%$ of respondents stated that their savings retention duration was shorter than one month. In comparison, almost one-fifth (17.5\%) of respondents indicated that they would not sustain on their savings alone in the absence of a monthly income.

Table 4.0: Retention Period with Savings

\begin{tabular}{lll}
\hline Duration & $\mathbf{n}$ & $\mathbf{\%}$ \\
\hline No retention period & 75 & $17.9 \%$ \\
$<1$ month & 118 & $28.1 \%$ \\
$1-3$ month & 131 & $31.2 \%$ \\
$3-6$ month & 48 & $11.4 \%$ \\
$6-12$ month & 27 & $6.4 \%$ \\
$>12$ month & 21 & $5.0 \%$ \\
\hline
\end{tabular}

Table 4.0 revealed that almost half (a total of $46 \%$ ) of the respondents admit that their savings cannot sustain for even one month after taking current liabilities into account if being retrenched or out of business. Among these, almost one-fifth (17.9\%) of all the respondents indicated that they would not sustain their savings alone in the absence of a monthly income. These households may be considered vulnerable and would be much affected economically due to any changes to their income. This view on the vulnerability status of the respondents can be justified by the scholars' suggestions for sufficient emergency funds in the event of an income disruption. Though the suggestions vary among those scholars, the minimum suggestion is at least two and a half months of living expenditure.

Greninger et al (1996) agreed that at least two and a half to three months of living expenditures should be comparable to liquid assets in the event of an emergency. At the same time, Garman and Forgue (2006) suggest an almost similar minimal level of sufficiency that is 
three months' of the living costs on the same basis of living expenditure. Concerning these suggestions, another group having almost one-third of the respondents (31.2\%) who can sustain for slightly a more extended time for one to three months with their savings will also be considered vulnerable. Thus, a total of slightly more than three-quarters (77.2\%) of these B40 respondents are at risk of surviving upon being jobless or losing their income.

A good principle is that consumers should keep sufficient liquid assets to cover three to six months of typical labour spending since a laid-off worker is said to be reemployed after three or six months (Johnson \& Widdows, 1985). However, those stated that they could survive more than three months with their savings are only less than a quarter (a total of $22.8 \%$ ) if being retrenched. At this stance, less than a quarter of these B40 respondents could be considered as not vulnerable. Ample time is needed to search for new jobs opening and job offers. There may be many job vacancies advertised. However, most jobs have specific requirements that may not match the candidate experience. Even though it fits, the location might be the issue. At times of economic uncertainties, especially during pandemics like the current situation, unemployment increased from 2.3 per cent in 2019 to 5.3 per cent in May 2020 after the pandemic strikes and the Movement Control Order was imposed. The rate is still high at 4.8 per cent in June 2021 (Department of Statistics Malaysia, 2021). Job offers may be limited and have stringent requirements. Hence, there is a low possibility of securing a new job in a short period, such as less than three months.

\section{Model Fitness}

The fitness of the financial well-being model was indicated by an R square value of 0.386 , where the model explained 38.6 per cent of the variances in financial well-being. The first model explained financial well-being by factors comprising financial behaviour, financial stress, and internal and external locus of control.

Table 5.0: Fitness of the financial well-being model

\begin{tabular}{ccccc}
\hline Model & $\mathrm{R}$ & $\mathrm{R}$ Square & $\begin{array}{c}\text { Adjusted } \mathrm{R} \\
\text { Square }\end{array}$ & $\begin{array}{c}\text { Std. Error of the } \\
\text { Estimate }\end{array}$ \\
\hline 1 & $.621^{\mathrm{a}}$ & .386 & .380 & 4.64163 \\
\hline
\end{tabular}

a. Predictors: (Constant), Financial Behaviour, Financial Stress, Internal LOC, External LOC

b. Dependent Variable: Financial Well-Being

\section{Regression Results for Financial Well-being Model}

The statistical significance model indicated significant F-ratio ( $F=65.70 ; p=.000)$ were valid models based on the ANOVA output. Hence, the regression model is a good fit for the data.

Table 6.0: ANOVA Results for Regression

\begin{tabular}{ccccccc}
\hline & Model & Sum of Squares & df & $\begin{array}{c}\text { Mean } \\
\text { Square }\end{array}$ & F & Sig. \\
\hline 1 & Regression & 5686.556 & 4 & 1421.639 & 65.702 & $.000^{\mathrm{b}}$ \\
& Residual & 9044.525 & 418 & 21.638 & & \\
& Total & 14731.081 & 422 & & & \\
\hline
\end{tabular}

a. Dependent Variable: Financial Well-Being 
b. Predictors: (Constant), Financial Behaviour, Financial Stress, External locus of control, Internal locus of control,

The influence of financial behaviour, financial stress, internal and external locus of control are shown in Table 7.0. All variables in Model 1 - financial behaviour and internal locus of control were found to positively impact financial well-being, except financial stress was negatively influencing financial well-being. This study corroborates Garman and Forgue's findings (2006), who claimed that healthy financial behaviour adds to high financial well-being, poor financial management is negative and would cause financial issues. A growing amount of evidence supports the hypothesis that if people engaged in better financial behaviour, their financial well-being would improve (Godwin, 1994; Joo \& Grable, 2004; Kim \& Garman, 2003).

Financial stress occurs when a person's financial resources are insufficient to meet basic financial needs to maintain a specific level of living. Henceforth, those under much financial stress must engage in proper financial activities to be more financially independent.

All three independent variables, financial behaviour, financial stress and internal locus of control, were significant. Hence, hypotheses $\mathrm{H} 1, \mathrm{H} 2$, and $\mathrm{H} 3$ were accepted. The variable, financial behaviour, was the strongest influence on the financial well-being of the $B 40$ Household in Selangor $(\beta=0.34)$, followed by an internal locus of control $(\beta=0.308)$. The beta values indicate the proportion of independent factors used to characterise the dependent variable. In contrast, the significant value indicates whether or not the independent variables' influence is significant when predicting the dependent variable.

Table 7.0: Regression Results for Financial Well-Being

\begin{tabular}{llllll}
\hline Model & & B & Beta & t & Sig. \\
\hline 1 & (Constant) & 5.313 & & 3.437 & .001 \\
& Financial Behaviour & .388 & .341 & 7.945 & $.000^{* *}$ \\
& Financial Stress & -.310 & -.284 & -7.084 & $.000^{* *}$ \\
& Internal Locus of Control & .768 & .308 & 6.923 & $.000^{* *}$ \\
& External Locus of Control & .146 & .075 & 1.808 & .071 \\
\hline
\end{tabular}

$$
* p \leq .05 ; * * \leq .01
$$

This study presents empirical data in support of evidence-based policymaking. When it comes to one's financial well-being, B40 is the most vulnerable group. The results show a significant positive relationship between financial behaviour and financial well-being. Thus the authorities must facilitate roadshows to instil positive financial behaviours in the B40 group, such as budgeting, cash flow planning, and debt management, to put them on the road to better financial well-being.

These low-income groups could also benefit from motivational seminars to strengthen their internal LOC and empower them to take action on their financial future. Even though this study is limited to Malaysia, its findings and conclusions could be relevant to other emerging markets, especially those in low and middle-income economies. 


\section{Conclusion and Implementation}

Several factors were found to be significantly affecting the financial well-being of B40 households. The influential factors affecting the financial well-being of B40 households are found to be financial behaviour, financial stress and internal locus of control. The finding suggests empirical evidence that could be used to assist evidence-based policymaking. The B40 income group is financially fragile, and the results show a significantly positive relationship between financial behaviour and financial well-being. Hence, the authorities should organize road demonstrations to inspire positive financial conduct amongst the B40 Groups daily, such as budgeting for the financial, cash flow planning and debt management to improve future financial security.

Financial stress can lead to detrimental consequences, such as being increasingly depressed and restless with the current financial situation. Additionally, it contributes to the deterioration of physical and interpersonal health, which is consistent with research conducted previously by Coley and Lombardi (2014) and Subramaniam et al. (2014). In addition, motivating dialogues might be held amongst these susceptible groups to enhance the internal LOC to be more controlled and take charge of their lives' outcomes.

Financial activities that are well planned are important to those who can control their decisions to uplift their financial situation. Henceforth, those under much financial stress must engage in proper financial activities to be more financially independent. In summary, ensuring responsible practices, including excellent financial behaviour practices, strong financial stress management and high internal locus of control, strengthened to assist households in completing their financial management.

\section{Acknowledgment}

The authors wish to express their gratitude to the Ministry of Higher Education Malaysia for funding this study Long Term Research Grant Scheme-Malaysia Research University Network (LRGS-MRUN), project code (MRUN-2019-001/4) entitled "Determinants of Financial Wellbeing among B40 Households".

\section{References}

Aggarwal, S. (2014). Developing an index for measuring financial well-being in a grorsaphy. IFMR Finance Foundation.

Aldana, S. G., \& Liljengquist, W. (1998). Validity and reliability of a financial strain survey. Journal of Financial Counselling and Planning, 9(2), 11-19.

Anderson, N. B., Belar, C. D., Breckler, S. J., Nordal, K. C., Bal- lard, D. W., Bufka, L. F., \& Wiggins, K. (2015, February). Stress in America: Paying with our health. American Psychological Association.

Ayhan, H. Ö. (2011). Non-probability Sampling Survey Methods. In: Lovric M. (eds) International Encyclopedia of Statistical Science. Springer, Berlin, Heidelberg. https://doi.org/10.1007/978-3-642-04898-2_41

Benjamin, D. J., Heffetz, O., Kimball, M. S., \& Szembrot, N. (2014). Beyond happiness and satisfaction: Toward well-being indices based on stated preference. American Economic Review, 104(9), 2698-2735.

Bernard, H. R. (2002). Research methods in anthropology: Qualitative and quantitative approaches (3rd ed.). Walnut Creek, CA: Alta Mira Press. 
Board of Governors of the Federal Reserve System (2018). Report on the Economic Well-Being of U.S. Households in 2017.

Boss, P. (2001). Family stress management (2nd ed.). Newbury Park, CA: Sage Publications Inc.

Brewin, C. R., \& Shapiro, D. A. (1984). Beyond locus of control: Attribution of responsibility for positive and negative outcomes. British Journal of Psychology, 75(1), 43-49.

Brüggen, E. C., Hogreve, J., Holmlund, M., Kabadayi, S., \& Löfgren, M. (2017). Financial wellbeing: A conceptualization and research agenda. Journal of Business Research, 79, 228237.

Cobb-Clark, D. A., Kassenboehmer, S. C., \& Sinning, M. G. (2013). Locus of control and savings. IZA discussion paper No. 7837, December 2013.

Consumer Financial Protection Bureau. (2015b, December). Measuring Financial Well-Being: A Guide to Using the CFPB Financial Well-Being Scale. Retrieved on July 25, 2018 from https://files.consumerfinance.gov/f/201512_cfpb_financialwell-being-user-guidescale.pdf.

Deacon, R. E., \& Firebaugh, F. M. (1988). Family resource management: Principles and applications. New York: F. S. Allyn \& Bacon. 'íEEP'

Department of Statistics Malaysia (2021). Unemployment rate. Department of Statistics Malaysia.

Dew, J., \& Xiao, J. (2011). The financial management behaviour scale: Development and validation. Journal of Financial Counseling and Planning, 22, 43-59.

Drentea, P., \& Lavrakas, P. J. (2000). Over the limit: The association among health, race and debt. Social Science and Medicine, 50(4), 517-529.

Falahati, L., Sabri, M. F., \& Paim, L. H. (2012). Assessment a model of financial satisfaction predictors: Examining the mediate effect of financial behaviour and financial strain. World Applied Sciences Journal, 20(2), 190-197.

Fletcher, C. N., \& Lorenz, F. O. (1985). Structural influences on the relationship between objective and subjective indicators of economic well-being. Social Indicators Research, 16(3), 333-345.

Garman, E. T., \& Forgue, R. E. (2006). Personal finance (7th ed.) Houghton Mifflin Co.

Godwin, D. D. (1994). Antecedents and consequences of newlyweds' cash flow management. Financial Counseling and Planning, 5, 161-190.

Godwin, D. D. (1994). Antecedents and consequences of newlyweds' cash flow management. Financial Counselling and Planning, 5, 161-190.

Gorham, E. E., DeVaney, S. A., \& Bechman, J. C. (1998). Adoption of financial management practices: A program assessment. Journal of Extension, 36(2), 1-9.

Greninger, S. A., Hampton, V. L., Kitt, K. A., \& Achacoso, J. A. (1996). Ratios and benchmarks for measuring the financial well-being of families and individuals. Financial Services Review, 5(1), 57-70.

Hellriegel, D., Slocum, J. W., \& Woodman, R. W. (2010). Organizational behaviour. Mason: South-Western Cengage Learning.

Hilgert, M. A., \& Hogarth, J. M. (2003). Household financial management: The connection between knowledge and behaviour. Federal Reserve Bulletin, 88, 309-322.

Hoffman, D. L., Novak, T. P., \& Schlosser, A. (2000). Consumer control in online environments. Working paper, eLab, Owen Graduate School of Management, Vanderbilt University. 
Hogarth, J. M., and Anguelov, C. E. (2004). Are families who use e-banking better financial managers? National Endowment for Financial Education, 19, 1- 34. http://dx.doi.org/10.1016/S1057-0810(96)90027-X

Ismail, M. K., Kumaran, V. V., \& Munawwarah, S. N. (2021). COVID-19 Outbreak: An Analysis of Malaysian Household Income Class During Movement Control Orders (MCO). Asia Proceedings of Social Sciences, 7(1), 26-29. https://doi.org/10.31580/apss.v7i1.1738

Jacobson, B. H., Aldana, S. G., Goetzel, R. Z., Vardell, K. D., Adams, T. B., \& Pietras, R. J. (1996). The relationship between perceived stress and self-reported illness-related absenteeism. American Journal of Health Promotion, 11(1), 54-61.

Johnson, D., \& Widdows, R. (1985). Emergency fund levels of households. In K. Schnittgrund (Ed.), The Proceedings of the American Council on Consumer Interests 31th Annual Conference, 235-241.

Joo, S. (1998). Personal financial wellness and worker productivity. Unpublished doctoral dissertation, Virginia Polytechnic Institute and State University, Blacksburg.

Joo, S., \& Grable, J. E. (2004). An exploratory framework of the determinants of financial satisfaction. Journal of Family and Economic Issues, 25(1), 162-171. http://dx.doi.org/10.1023/B:JEEI.0000016722.37994.9f

Kapoor, J. R., Dlabay, L. R., \& Hughes, R. J. (2001). Personal Finance. Singapore: McGraw-Hill.

Kim, J., \& Garman, E. T. (2004). Financial stress, pay satisfaction and workplace performance, Compensation \& Benefits Review, 36, 69-76. http://journals.sagepub. com/doi/abs/10.1177/0886368703261215

Kim, J., Sorhaindo, B., \& Garman, E. T. (2006). Relationship between financial stress and workplace absenteeism of credit counseling clients. Journal of Family and Economic Issues, 27(3), 458-478.

Krejcie, R. V., \& Morgan, D. W. (1970). Determining sample size for research activities. Educational and psychological measurement, 30(3), 607-610.

Lefcourt, H. M. (1976). Locus of control and the response to aversive events. Canadian Psychological Review/Psychologie Canadienne, 17(3), 202-209.

Lyons, A. C., \& Yilmazer, T. (2005). Health and financial strain: Evidence from the survey of consumer finances. Southern Economic Journal, 71(4), 873-890.

Maloch, F., \& Deacon, R. E. (1966). Proposed framework for home management. Journal of Home Economics, 58(1), 31-35.

Mokhtar, N., \& Husniyah, A. R. (2017). Determinants of financial well-being among public employees in Putrajaya, Malaysia. Pertanika J. Soc. Sci. Hum, 25, 1241-1260.

Nickerson, C., Schwarz, N., \& Diener, E. (2007). Financial aspirations, financial success, and overall life satisfaction: Who? And how?. Journal of Happiness Studies, 8(4), 467-515.

O’Neill, B., Sorhaindo, B., Xiao, J. J., \& Garman, E. T. (2005). Financially distressed consumers: Their financial practices, financial well-being, and health. Journal of Financial Counseling and Planning, 16(1), 73-87.

O’Neill, B., Xiao, J. J., Bristow, B., Brennan, P., \& Kerbel, C. M. (2000). Successful financial goal attainment: Perceived resources and obstacles. Journal of Financial Counseling and Planning, 11(1), 1-12.

O'Neill, R. (2002). The Fatherless Family. London: The Institute for the Study of Civil Society.

OECD, O. (2013). INFE Toolkit to Measure Financial Literacy and Financial Inclusion: Guidance, Core Questionnaire and Supplementary Questions.

Por, J., Barriball, L., Fitzpatrick, J., \& Roberts, J. (2011). Emotional intelligence: its relationship to stress, coping, well-being and professional performance in nursing students. Nurse 
education today, 31(8), 855-860

Porter, N. M. (1990). Testing a model of financial wellbeing. Financial Counseling and Planning, 4, 135-164.

Porter, N. M. and Garman, E. T. (1993). Testing a conceptual model of financial well-being. Financial Counseling and Planning, 4, 135-165.

Prawitz, A. D., Garman, E. T., Sorhaindo, B., O’Neill, B., Kim, J., \& Drentea, P. (2006). InCharge financial distress/financial well-being scale: development, administration, and score interpretation. Financial Counseling and Planning. 17(1), 34-50.

Prawitz, A. D., Kalkowski, J. C., \& Cohart, J. (2013). Responses to economic pressure by lowincome families: Financial distress and hopefulness. Journal of Family and Economic Issues, 34(1), 29-40.

Rotter, J. B. (1966). Generalized expectancies for internal versus external control of reinforcement. Psychological Monographs: General and Applied, 80(1), 1-28.

Sabelhaus, J., \& Manchester, J. (1995). Baby Boomers and Their Parents: How Does Their Economic Well-Being Compare in Middle Age? Journal of Human Resources, 791-806.

Sabri, M. F., \& Zakaria, N. F. (2015). The influence of financial literacy, money attitude, financial strain and financial capability on young employees' financial well-being. Pertanika Journal of Social Sciences and Humanities, 23(4), 827-848.

Salamanca, N., de Grip, A., Fouarge, D., \& Montizaan, R. M. (2016). Locus of control and investment in risky assets. IZA Discussion Paper No. 10407. Retrieved December 3, 2018, from https://ssrn.com/abstr act=2886778.

Shim, S., Xiao, J. J., Barber, B. L., \& Lyons, A. C. (2009). Pathways to life success: A conceptual model of financial well-being for young adults. Journal of Applied Developmental Psychology, 30(6), 708-723.

Starrin, B., Åslund, C., \& Nilsson, K. W. (2009). Financial stress, shaming experiences and psychosocial III health: Studies into the finances-shame model. Social Indicators Research, 91(2), 283-298. https://doi.org/10.1007/s11205-008-9286-8.

Subramaniam, G., Ali, E., \& Maniam, B. (2014). Subjective financial well-being and incidence of indebtedness among young workers in Malaysia. Business Studies Journal, 6, 57-

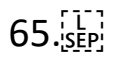

Sumarwan, U., \& Hira, T. K. (1993). The effects of perceived locus of control and perceived income adequacy on satisfaction with financial status of rural households. Journal of Family and Economic Issues, 14(4), 343-364.

Taft, M. K., Hosein, Z. Z., Mehrizi, S. M. T., \& Roshan, A. (2013). The relation between financial literacy, financial wellbeing and financial concerns. International Journal of Business and Management, 8(11), 63.

Tongco, M. D. C. (2007). Purposive sampling as a tool for informant selection. Ethnobotany Research and applications, 5, 147-158.

Van Praag, B. M., Frijters, P., \& Ferrer-i-Carbonell, A. (2003). The anatomy of subjective wellbeing. Journal of Economic Behaviour \& Organization, 51(1), 29-49.

Voydanoff, P. (1990). Economic distress and family relations: A review of the eighties. Journal of Marriage and the Family, 52(4), 1099-1115. https://doi.org/10.2307/351841.

Williams, F. I. (1983). Money income, no money income, and satisfaction as determinants of perceived adequacy of income. Paper presented at the perceived economic wellbeing symposium, Urbana.

Xiao, J. J. (Ed.). (2008). Applying behavior theories to financial behavior. In Handbook of consumer finance research (pp. 69-81). New York: Springer. 
Xiao, J. J., Chen, C., \& Chen, F. (2014). Consumer financial capability and financial satisfaction. Social Indicators Research, 118(1), 415-432. SE-pis

Xiao, J. J., Sorhaindo, B. and Garman, E. T. (2004). Financial behaviours of consumers in credit counseling. Consumer Interest Annual, 50, 131-133.

Xiao, J. J., Sorhaindo, B., \& Garman, E. T. (2006). Financial behaviours of consumers in credit counselling. International Journal of Consumer Studies, 30, 108-121. https://doi.org/10.1111/j.1470-6431.2005.00455.x.s[ip]

Xiao, J. J., Tang, C., \& Shim, S. (2009). Acting for happiness: Financial behaviour and life satisfaction of college students. Social Indicators Research, 92(1), 53-68.

Yates, J. (2007). Housing affordability and financial stress. Research Paper, 6. 